\title{
Conjoint Use of Regression Analysis and Functional Measurement to Test Models of Combination of Factors Predicting Negative Attitude to Women*
}

\section{Utilización conjunta del análisis de regresión y de la medida funcional para poner a prueba modelos de combinación de predictores de las actitudes negativas hacia las mujeres}

Received: 02 November 2017 | Accepted: 25 January 2018

\begin{abstract}
Asli Bugay ${ }^{\mathrm{a}}$
Middle East Technical University, Turkey

Rakel Delevi ORCID: https://orcid.org/0000-0002-3145-2654
\end{abstract}

California State University, United States of America

Etienne Mullet

Institute of Advanced Studies (EPHE), Paris, France ORCID: https://orcid.org/0000-0002-1707-3914
${ }^{a}$ Correspondence author. Email: abugay00@gmail.com

How to cite: Bugay, A., Delevi, R., \& Mullet, E. (2019). Conjoint use of regression analysis and functional measurement to test models of combination of factors predicting negative attitude to women. Universitas Psychologica, 18(3), 1-7. https://doi.org/10.11144/ Javeriana.upsy18-3.cura

\begin{abstract}
The present study was aimed at showing that by conjointly using two techniques that are rarely used in combination - regression analysis and functional measurement, it may be possible to rigorously tests models of combination of factors using data obtained in traditional multi-item/ multi-scale surveys. The data used for this demonstration were taken from a large survey $(N=3,235)$ of Turkish students' attitude to women (ATW). As it included 12 types of predictors (e.g., age, geographic location, score on collectivism scales), stepwise regression analysis was firstly used to select a subset of predictors. Three of them explained the major part of variance: biological gender (sex), level of political conservatism in the area (the place factor), and personal score on the vertical individualism scale (the culture factor). Secondly, continuous conservatism and collectivism scores were categorized into three levels and three factorial plots were created -. one for each level of support for conservatism -- with ATW on the y-axis, vertical collectivism on the $\mathrm{x}$-axis, and biological sex on curves. Divergence of curves observed in all panels supported a multiplicative-type model of combination of the gender and culture factors. As a result, the model of combination of factors suggested was: Negative Attitude to Women $=($ Gender $\mathrm{x}$ Culture $)+$ Place.
\end{abstract}

Keywords

regression analysis; functional measurement; attitude to women; gender; place; culture; Turkey.

\section{RESUMEN}

El estudio demuestra que utilizando dos técnicas que no son frecuentemente empleadas juntas - análisis de regresión y medida funcional - resulta posible poner a prueba de forma rigurosa modelos 
hipotéticos de combinación de factores a partir de datos procedentes de cuestionarios habituales con varios ítems. Los datos utilizados para ilustrar esa posibilidad fueron tomadas de un encuesta realizada en Turquía $(\mathrm{N}=3,235)$ sobre la actitud de los estudiantes hacia las mujeres. Dado que el cuestionario utilizado inclúyala 12 tipos de predictores de esas actitudes (ej., edad, lugar de residencia, nivel de colectivismo-individualismo), un análisis de regresión paso a paso fue aplicado de manera a seleccionar un conjunto reducido de predictores independientes. Tres de los 12 explicaban la mayor parte de la varianza: sexo (el factor Biológico), nivel de conservatismo político en la zona de residencia (el factor Lugar), y la puntuación personal en la escala de individualismo vertical (el factor Cultura). Luego, las escalas continuas de colectivismo y de conservatismo fueron categorizadas en tres niveles. Tres cuadros factoriales fueron creados - uno por cada nivel de conservatismo - con la actitud negativa hacia las mujeres en el eje vertical, el nivel de colectivismo vertical en el eje horizontal y el sexo en las curvas. La divergencia sistemática hacia la derecha de las curvas, observa en cada de los tres cuadros, soporta un modelo de combinación de los predictores de tipo multiplicativo tratándose del factor sexo y del factor cultura. Como consecuencia, el modelo de combinación de los tres factores retenido fue: Actitud negativa hacia las mujeres $=($ Sexo $\mathrm{x}$ Cultura $)+$ Lugar

Palabras clave

análisis de regresión; medida funcional; actitudes hacia las mujeres; colectivismo; conservatismo.

Attitude to women (ATW) is associated to actual violence against women (Bhanot \& Senn, 2007) and to other related constructs such as conceptualization of rape (Lee, Kim, \& Lim 2010), acceptance of women's right to abortion (Patel \& John, 2009), and personal consumption of pornography (McKee, 2007).

ATW have been shown to depend on three kinds of factors: Gender, place and culture. Gender plays, unsurprisingly, an important role in shaping ATW: In most places and cultures, men are, in this respect, more traditional than women (Garcia-Moreno et al., 2006; Whatley, 2008). Place also plays an important role. Studies conducted in western countries have reported more positive ATW among male and female participants than studies conducted in other countries (Ikhlas, 1996). Finally, culture plays a non-negligible role (Kashima et al., 1995; Roberts \& Helson, 1997; Zhang, Mandl, \& Wang 2011). People scoring high in individualism (disposition to valuing individual uniqueness and self-determination) and low in verticality (disposition to valuing hierarchy and authority) report more positive ATW than students scoring low in individualism and high in verticality.

Although many studies have been conducted that included gender, place and/or cultural factors, no one has until now tested the algebraic model of combination of these factors. The present study was aimed at showing that by conjointly using two techniques that are rarely used in combination - regression analysis and functional measurement, it may be possible to do so in a rigorous way.

\section{Using regression analysis to determine which measurements should be included in the model}

The present study was conducted in Turkey (Bugay, Delevi, \& Mullet, 2019). A total of 3,235 voluntary, non-remunerated students (aged 18-25, 70\% females) from 16 universities (see Table 1) participated. Gender-related factors were mesured using the Turkish version $(\mathrm{Ozkan}$ \& Lajunen, 2005) of the 30-item form of the Bem Sex Roles Inventory (Bem, 1981). The femininity subscale includes traits that are perceived as characteristic of women (e.g., emotional, sympathetic, and understanding), and the masculinity subscale traits that are perceived as men's ones (e.g., assertive, strong personality, and dominant). Biological sex was also included as a factor. 


\section{Table 1}

Number of participants from each university. Scores on the ATW scale, and on two of the Individualism-Collectivism subscales. Support for conservative politics for each geographic area.

\begin{tabular}{|c|c|c|c|c|c|c|c|}
\hline \multirow{2}{*}{ University } & \multirow{2}{*}{$\mathbf{N}$} & \multirow{2}{*}{$\begin{array}{l}\text { Percent. } \\
\text { Females }\end{array}$} & \multicolumn{2}{|c|}{$\begin{array}{l}\text { Attitude to } \\
\text { Women }\end{array}$} & \multirow{2}{*}{$\begin{array}{l}\text { Conser- } \\
\text { vatism }\end{array}$} & \multicolumn{2}{|c|}{ Culture } \\
\hline & & & Females & Males & & $\begin{array}{l}\text { Vertical } \\
\text { Coll. }\end{array}$ & $\begin{array}{l}\text { Horiz. } \\
\text { Indiv. }\end{array}$ \\
\hline Dokuz Eylül Üniv. (Izmir) & 129 & 74 & 43.1 & 38.7 & 33 & 32.3 & 40.2 \\
\hline Ege Üniv. (Izmir) & 117 & 79 & 43.1 & 38.4 & 33 & 32.2 & 40.6 \\
\hline Ankara Üniv. (Ankara) & 146 & 86 & 42.5 & 37.4 & 51 & 31.8 & 39.6 \\
\hline Çukurova Üniv. (Adana) & 165 & 71 & 41.9 & 37.6 & 39 & 32.4 & 40.2 \\
\hline Hacettepe Üniv. (Ankara) & 153 & 86 & 42.4 & 37 & 51 & 31.8 & 39.5 \\
\hline Marmara Üniv. (Istanbul) & 124 & 73 & 41 & 37.5 & 50 & 33.1 & 40.4 \\
\hline Anadolu Üniv. (Eskisehir) & 194 & 69 & 41.8 & 35.1 & 45 & 33.9 & 39.4 \\
\hline $\begin{array}{l}\text { Onsekiz Mart Üniv. } \\
\text { (Canakkale) }\end{array}$ & 247 & 68 & 39.8 & 36.7 & 42 & 34.5 & 40 \\
\hline İ̀stanbul Üniv. (Istanbul) & 199 & 66 & 41.3 & 34.8 & 50 & 33.5 & 40.5 \\
\hline Akdeniz Üniv. (Antalya) & 150 & 79 & 41 & 33.5 & 42 & 34.8 & 39.9 \\
\hline $\begin{array}{l}\text { Ondokuz Mayis Üniv. } \\
\text { (Samsun) }\end{array}$ & 251 & 65 & 39.9 & 34.1 & 66 & 34.8 & 40.1 \\
\hline Karad.Tekn. Üniv. (Trabzon) & 266 & 72 & 37.6 & 33.3 & 70 & 34.2 & 39.4 \\
\hline Kırıkkale Üniv. (Kirikkale) & 292 & 66 & 38.1 & 32.4 & 64 & 36.1 & 41.2 \\
\hline Gaziantep Üniv. (Gaziantep) & 294 & 61 & 36.9 & 32.5 & 60 & 35.3 & 39.9 \\
\hline İnönü Üniv. (Malatya) & 289 & 63 & 37.9 & 31.5 & 70 & 35.3 & 40.2 \\
\hline Atä̈rk Üniv. (Erzurum) & 219 & 63 & 36.4 & 31.5 & 69 & 35.8 & 39.8 \\
\hline Overall $(M)$ & 3,235 & 70 & 39.9 & 34.1 & & 34.2 & 40.1 \\
\hline Overall $(S D)$ & & & 5.3 & 7 & & 4.5 & 4.7 \\
\hline
\end{tabular}

Place was measured using a geographical index -- the longitude of the city in which participants were studying, and a socio-political index .. the local level of support for the conservative candidate at the last presidential elections of 2014; that is, at the time the study was conducted (see Table 1).

Culture was measured using the Turkish version (Wasti \& Erdil, 2007) of the 37-item form of the Individualism-Collectivism scale (Singelis, Triandis, Bhawuk, \& Gelfand, 1995). This scale is composed of four subscales: vertical individualism, vertical collectivism, horizontal individualism and horizontal collectivism. Vertical individualists are motivated to attain high social statuses in society, and having it recognized by others (e.g., "It is important that I do my job better than others"). Vertical collectivists also emphasize social status but they are more compliant with authority, and even ready to give up personal goals (e.g., "Family members should stick together, no matter what sacrifices are required"). Horizontal individualists prefer to view themselves as equal to others (e.g., "I'd rather depend on myself than on others"). Horizontal collectivists tend to value interdependence between people in addition to equality (e.g., "If a coworker gets a prize, I would feel proud").
Finally, attitude to women, the criterion, was measured using the Turkish version (Delevi \& Bugay, 2013) of the 12-item short form of the ATW Scale (Spence, Helmreich, \& Stapp, 1973). This scale measures normative expectations regarding the roles and behaviors of women in daily life (e.g., "Both husband and wife should be allowed the same grounds for divorce").

The survey took place during regular classes. Completion lasted approximately 10-15 minutes. Some of the mean results are shown in Table 1.

To determine which measurements should be included in the model of combination of factors, a stepwise regression analysis was conducted with ATW as the criterion and all other variables as predictors. Age, grade and socio-economic status were also included as predictors. Four predictors were selected, biological gender $(\beta=-0.39)$, local level of political conservatism $(\beta=-0.24)$, vertical collectivism $(\beta=-0.23)$, and horizontal individualism $(\beta=-0.15), F(4,3230)=367.55$, $p<0.001$. They explained $31 \%$ of the total variance in ATW scores $(R=0.56)$. No other predictor added any significant part of explained variance.

\section{Using functional measurement to determine which model of prediction of negative attitude to women best fit the data}

Functional measurement (FM) is most often used to characterize information integration rules used by people in judgment tasks such as quickly assessing the weight of an (unknown) object from its volume and its density before lifting it in order to prepare for adequate body posture (Léoni, Mullet, \& Chasseigne, 2002). In order to test integration rules, several situations are usually created by orthogonally varying the levels of the factors implicated in the situation, here volume and density. These situations are presented to participants who are asked to assess weight in each case using continuous scales ranging from low weight to high weight. Factorial plots are created with participant's assessement on the $y$ - 
axis, volume levels on the x-axis, and density levels as curves (see Figure 1). The pattern of responses observed allows diagnosing the type of integration rule used. Parallelism of curves is the signature of additive-type rules (summation rule or equal-weight averaging rule). Divergence of curves is the signature of multiplicative-type rules (muliplication rule or differential weight averaging rule). Convergence of curves usually indicates averaging processes (Anderson, 1982).

\section{Figure 1}

Three information integration rules.
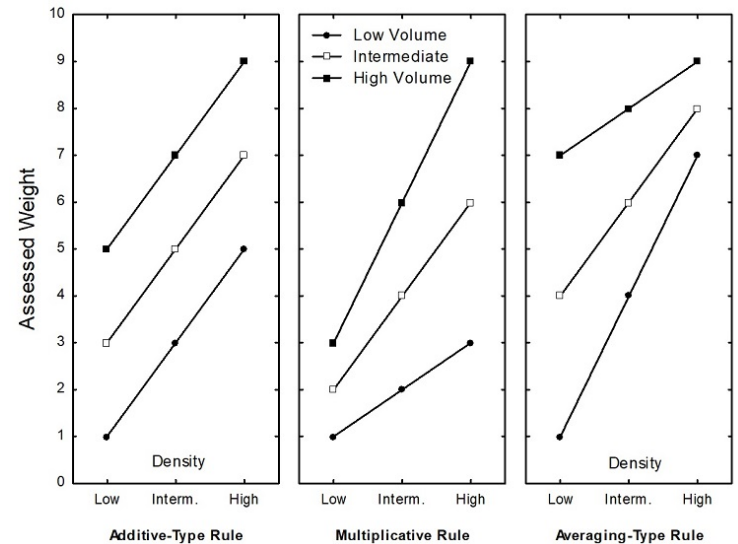

Assessed weight is on the y-axis, density levels are on the $\mathrm{x}$-axis. The three curves correspond to three density levels. The central panel shows the normative pattern; that is, the pattern that results from the application of the weight $=$ volume $\mathrm{x}$ density physical law. The left panel shows a pattern that is often observed among young pupils. The right panel shows a pattern that has been observed among few participants in previous studies.

Although FM has been most often used in the context of human judment studies using within-subject designs (e.g., Mullet et al., 2016), its principles (e.g., the parallelism theorem) are, under some conditions, generalizable to any kind of measurement. In other words, the use of FM principles is not limited to ratings given on continuous scales by participants exposed to varying levels of separate factors. Any kind of data may be, under some conditions, analyzed using the FM principles.

For example, Farley and Fantino (1978) used functional measurement to relate the number of pecks given by pidgeons as a function of two factors: food delivery and electric shocks. The pattern of responses they found was similar to the one shown in Figure 1 (center panel). Pereira, Oliveira and Fonseca (2016) examined patterns of cortical activation in an integration task using pairs of emotional faces. They found support for adding-type rules (see left hand panel of Figure 1). Mairesse et al. (2010) suggested using functional measurement for relating current perceived sleepiness to objective, external factors such as time of day and level of sleep deprivation (number of hours slept during previous night). Mullet and Chasseigne (2018) have shown that FM can also be applied when between-subjet designs were used, and that the same rules (see Figure 1) are found.

\section{Figure 2}

Relationhip between attitude to women (y-axis), vertical collectivism ( $x$-axis), biological sex (curves) and political conservatism in the area (panels).
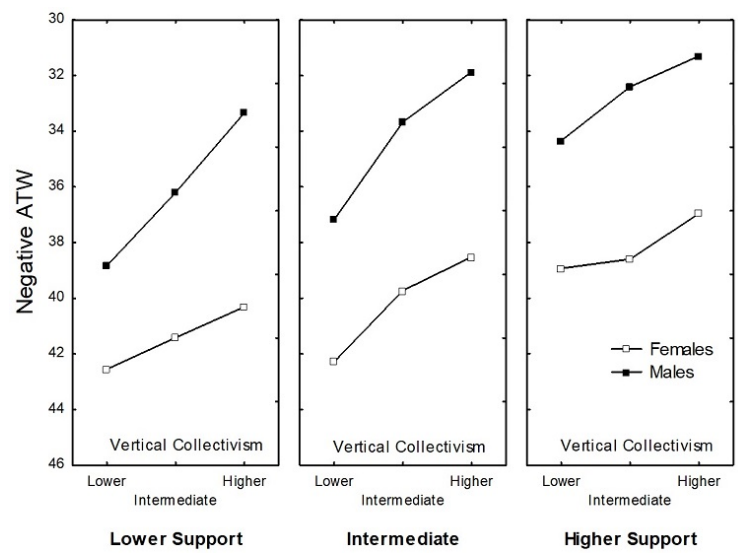

In all panels, curves are ascending, separated, and diverge on the right, which is the signature of a multiplicative rule of combination of effects.

In order to test whether the model of combination of gender, place and culture factors obeyed an additive rule, a multiplicative rule, an additive-multiplicative rule or another kind of rule, political conservatism and vertical collectivism measurements were transformed into 1-3 scores: low, medium, and high. Figure 2, which plots ATW scores (inversed) as a function of these factors and of biological gender, shows that in all panels, curves are ascending, separated and diverge on the right. In other words, a Gender x Vertical Collectivism interaction was present, and this interaction was concentrated in 
its bilinear component, $F(1,3217)=13.17, p<$ 0.001. Among males $(36.79-32.14=4.65)$, the impact of vertical collectivism was stronger than among females $(41.25-38.59=2.66)$.

\section{Discussion}

As in previous studies (for a review, see Bugay et al., 2019; Twenge, 1997), gender impacted on ATW. Males expressed more traditional views than females. The male-female difference between ATW scores corresponded to $17 \%$ of the range of the response scale. As expected, place -- level of political conservatism in the area -- had also a strong impact on ATW. The difference between scores observed in Izmir and Erzurum corresponded to $20 \%$ of the range of the scale. Place and gender added their effect on ATW to the point that the average female student in Erzurum expressed more traditional views regarding women than the average male student in Izmir.

As expected, culture had an impact on people's ATW, but this impact differed from one aspect of culture to the other. It was essentially attributable to vertical collectivism (emphasis on hierarchy and inequality in society) and, to a more limited extent, to horizontal individualism (viewing oneself as equal to others) (Zhang, Mandl, \& Wang, 2011). Culture and gender interacted. The impact of culture was stronger among males than among females. The model of combination of effects can therefore be expressed as:

Negative Attitude to Women $=($ Gender $\times$ Vertical Collectivism $)+$ Political Conservatism $(1)$

Equation 1 suggests a more general model that could be tested in additional studies:

Negative Attitude to Women $=($ Gender $\times$ Culture $)+$ Place

In conventional IIT studies, the exact nature of the + and operators in Equation (1) could be determined in subsequent studies by (a) varying the number of factors included in the experiment, and (b) comparing judgments given in complete information situations (with all three factors present) and judgments given in incomplete information situations (with only two of the three factors present) (Anderson, 1982). In studies of the present type, manipulations of this kind cannot be considered. Combination of the gender and place factors, for example, does not take place in the internal world of the human brain. They occur in the external world. Their nature is, therefore, different. Divergence of curves in Figure 2 means that the effect of culture is truly potentiated by gender, in the same way as the effect of sleeping pills on may be potentiated by alcohol intake.

\section{Methodological implications}

The strength of regression analysis is that it allows detecting strong, promising predictors among a set of factors that can be large (here, twelve). By including composite terms (e.g., gender x place) as additional predictors, regression analysis also allows testing interactive, non-additive models. In most cases, however, statistical power is usually lacking for allowing efficient tests of interactions. Regression analysis is therefore limited in its ability to rigorously test integration models, and usually bounded to postulate additivity of effects (Anderson, 2001).

The strength of FM is that it allows rigorously testing combination of effects models. In the present study, (a) divergence of curves in each panel supported a multiplicative model of combination of the gender and culture factors, (b) parallelism of curves across panels supported an additive model of combination of the place and gender factors, and (c) both parallelism and divergence observed on the same data indicated that the values taken by the criterion were true linear measures of ATW and that the way preditor values were categorized (1-3 scores) was valid (Anderson, 2016). The main limitation of functional measurement resides, however, in that only a small number of factors can be considered in each experiment, usually from two to four.

The synergy of approaches is therefore apparent: Functional measurement may vastly increase the precision with which models of integration can be tested, while regression 
analysis may vastly increase the number of factors that can be simultaneously considered in a single study.

\section{References}

Anderson, N. H. (2001). Empirical direction in design and analysis. Mahwah, NJ: Lawrence Erlbaum Associates. https://doi.org/10.432 4/9781410600004

Anderson, N. H. (2008). Unified social cognition. New York, NY: Psychology Press.

Anderson, N. H. (2016). Information integration theory: Unified psychology based on three mathematical laws. Universitas Psychologica, 15(3). http://dx.doi.org/10.11144/Javerian a.upsy15-3.iitu

Bhanot, S., \& Senn, C. Y. (2007). Attitudes towards violence against women in men of South Asian ancestry: Are acculturation and gender role attitudes important factors? Journal of Family Violence, 22, 25-31. https:/ /doi.org/10.1007/s10896-006-9060-0

Bem, S. L. (1981). Bem sex-role inventory: Professional manual. Palo Alto, CA: Consulting Psychologists Press.

Bugay, A., Delevi, R., \& Mullet, E. (2019). Attitude to women in Turkey. Current Psychology, 1-9. https://doi.org/10.1007/ s12144-019-00273-2

Delevi, R., \& Bugay, A. (2013). Assessing reliability and validity of the 15 -item short version of the Attitudes Toward Women Scale (AWS) among Turkish students. Journal of International Women's Studies, 14(1), 263-272. Retrieved from https://vc.b ridgew.edu/jiws/vol14/iss1/16

Farley, J., \& Fantino, E. (1978). The symmetrical law of effect and the matching relation in choice behavior. Journal of the Experimental Analysis of Behavior, 29(1), 37-60. https://d oi.org/10.1901/jeab.1978.29-37

Garcia-Moreno, C., Jansen, H. A. F. M., Ellsberg, M., Heise, L., Watts, C., on behalf of the WHO Multi-country Study on Women's Health and Domestic Violence against Women Study Team (2006). Prevalence of intimate partner violence: Findings from the WHO Multi-Country Study on women's health and domestic violence. The Lancet, 368(9543), 1260-1269. https://doi. org/10.1016/S0140-6736(06)69523-8

Ikhlas A. A. (1996). Attitudes towards women in the Arabian Gulf region. Women in Management Review, 11(1), 29-39. https://d oi.org/10.1108/09649429610109271

Kashima, Y., Yamaguchi, S., Kim, U., Choi, S.C., Gelfand, M. J., \& Yuki, M. (1995). Culture, gender, and self: A perspective from individualism-collectivism research. Journal of Personality and Social Psychology, 69(5), 925-937. http://dx.doi.org/10.1037/ 0022-3514.69.5.925

Lee, J., Kim, J., \& Lim, H. (2010). Rape myth acceptance among Korean college students: The roles of gender, attitudes toward women, and sexual double standard. Journal of Interpersonal Violence, 25(7), 1200-1223. https://doi.org/10.1177/088626 0509340536

Léoni, V., Mullet, E., \& Chasseigne, G. (2002). Aging and intuitive physics. Acta Psychologica, 111(1), 29-43. https://doi.org/ 10.1016/S0001-6918(01)00077-4

Mairesse, O., Hofmans, J., Neu, D., de Oliveira, A., Cluydts, R., \&Theuns, P. (2010). The algebra of sleepiness: investigating the interaction of homeostatic (S) and circadian (C) processes in sleepiness using linear metrics. Psicólogica, 31, 541-559. Retrieved from https://www.uv.es/psicologi ca/articulos3FM.10/8Mairesse.pdf

McKee, A. (2007). Positive and negative effects of pornography as attributed by consumers. Australian Journal of Communication, 34(1), 87-104. Retrieved from https://eprints.qut. edu.au/14575/

Mullet, E., \& Chasseigne, G. (2018). Assessing information integration processes: A comparison of findings obtained with between-subjects designs versus withinsubjects designs. Quality $\mathcal{E}$ Quantity, 54(4), 1977-1988. https://doi.org/10.1007/s11135 $-017-0592-6$ 
Mullet, E., López López, W., Kpanake, L., Mukashema, I., Armange, R., Kamble, S., ... Neto, F. (2016). Functional measurement in the field of ethics in politics. Universitas Psychologica, 15(3), 1-26. https://doi.org/10.11144/Javeriana.up sy15-3.fmf

Ozkan, T., \& Lajunen, T. (2005). Masculinity, femininity, and the Bem Sex Role Inventory in Turkey. Sex Roles, 52 (1-2), 103-110. http s://doi.org/10.1007/s11199-005-1197-4

Patel, C. J., \& Johns, L. (2009). Gender role attitudes and attitudes to abortion: Are there gender differences? The Social Science Journal, 46(3), 493-505. https://doi.org/10. 1016/j.soscij.2009.02.006

Pereira, T., Oliveira, A., \& Fonseca, I. B. (2016). Brain activation follows addingtype integration laws: Brain and rating responses in an integration task with pairs of emotional faces. Universitas Psychologica, 15(3), 1-18. https://doi.org/10.11144/Javeri ana.upsy15-3.bafa

Roberts, B. W., \& Helson, R. (1997). Changes in culture, changes in personality: The influence of individualism in a longitudinal study of women. Journal of Personality and Social Psychology, 72 (3), 641-651. http://dx .doi.org/10.1037/0022-3514.72.3.641

Singelis, T. M., Triandis, H. C., Bhawuk, D. P. S., \& Gelfand, M. J. (1995). Horizontal and vertical dimensions of individualism and collectivism: A theoretical and measurement refinement. Cross-Cultural Research, 29(3), 240-275. https://doi.org/10 $.1177 / 106939719502900302$

Spence, J. T., Helmreich, R., \& Stapp, J. (1973). A short version of the Attitudes toward Women Scale (AWS). Bulletin of the Psychonomic Society, 2(4), 219-220. https:// doi.org/10.3758/BF03329252

Twenge, J. M. (1997). Attitudes toward women, 1970-1 995: A meta-analysis. Psychology of Women Quarterly, 21 (1), 35-51. https://doi. org/10.1111/j.1471-6402.1997.tb00099.x

Wasti, S. A., \& Erdil, S. E. (2007). Bireycilik ve Toplulukçuluk Değerlerinin Ölçülmesi: Benlik Kurgusu ve INDCOL Ölçeklerinin
Türkçe Geçerlemesi [The Turkish version of the Individualism-Collectivism scale]. Yönetim Arasttrmaları Dergisi, 7, 39-66.

Whatley, M. A. (2008). The dimensionality of the 15 Item Attitudes Toward Women Scale. Race, Gender $\mathscr{E}$ Class, 15(1-2), 265-273. Retrieved from https://www.jstor. org/stable/41675371

Zhang, J., Mandl, H., \& Wang, E. (2011). The effect of vertical-horizontal individualismcollectivism on acculturation and the moderating role of gender. International Journal of Intercultural Relations, 35(1), 124-34. https://doi.org/10.1016/j.ijintrel.20 10.09.004

\section{Notes}

* Research article. 